\title{
Biological nitrate removal in a laboratory-scale slow sand filter
}

\author{
Sukru Aslan* \\ Cumhuriyet University Department of Environmental Engineering 58140 Sivas/Turkey
}

\begin{abstract}
This research evaluated removal of nitrates from drinking waters in a slow sand filter (SSF). Batch experiments were performed to determine optimum carbon to $\mathrm{NO}_{3}-\mathrm{N}(\mathrm{C} / \mathrm{N})$ ratio for the filtration experiments. The filter column was filled with filter sand of an effective diameter of $0.5 \mathrm{~mm}$ and uniformity coefficient of 1.23 . The filter was operated at filtration rates of between 0.02 to $0.120 \mathrm{~m} / \mathrm{h}$ and 0.01 to $0.25 \mathrm{~m} / \mathrm{h}$ with concentrations of 22.6 and $45.2 \mathrm{mg} \mathrm{NO}-\mathrm{N} / \ell$, respectively, and effluent samples of the SSF were taken at 6 depths of $10,15,20,40,60,80 \mathrm{~cm}$, and the bottom. Optimum $\mathrm{C} / \mathrm{N}$ ratio was found to be 1.5 when using ethanol in batch tests when the removal efficiencies of $\mathrm{NO}_{3}-\mathrm{N}$ and $\mathrm{C}$ were higher than $90 \%$. Although increasing filtration rates decreased $\mathrm{NO}_{3}-\mathrm{N}$ removal, effluent $\mathrm{NO}_{3}-\mathrm{N}$ concentration at the effluent port of the SSF was lower than the limit value. Most of the $\mathrm{NO}_{3}-\mathrm{N}$ removal was carried out at the upper layer of $(10 \mathrm{~cm})$ the filter bed. Concentration of $\mathrm{NO}_{3}-\mathrm{N}$, $\mathrm{NO}_{2}-\mathrm{N}$, and $\mathrm{C}$ were not detected at the $60 \mathrm{~cm}$ depth of the SSF through the study for the inlet concentrations of $22.6 \mathrm{mg}$ $\mathrm{NO}_{3}-\mathrm{N} / \ell$. As expected, increasing influent $\mathrm{NO}_{3}-\mathrm{N}$ concentration to $45.2 \mathrm{mg} / \ell$ increased $\mathrm{NO}_{3}-\mathrm{N}, \mathrm{NO}_{2}-\mathrm{N}$, and $\mathrm{C}$ concentrations in the effluent water. The SSF process was unable to provide $\mathrm{NO}_{3}-\mathrm{N}$ removal rate of more than $228 \mathrm{~g} \mathrm{~N} / \mathrm{m}^{3} \cdot \mathrm{d}(0.2 \mathrm{~m} / \mathrm{h}$ flow rate, $217 \mathrm{~g} \mathrm{~N} / \mathrm{m}^{2} \cdot \mathrm{d}$ of surface loading rate). The $\mathrm{NO}_{3}-\mathrm{N}$ removal efficiency dropped slightly from 96 to $95 \%$ when the loading rate increased from 228 to $285 \mathrm{~g} / \mathrm{m}^{3} \cdot \mathrm{d}$, but the effluent water contained higher concentrations of $\mathrm{NO}_{2}-\mathrm{N}(8.4 \mathrm{mg} / \ell)$ than the standard value. The results of the SSF experiment demonstrated that averaged nitrogen conversion to volatile solids was about $0.77 \mathrm{mg} \mathrm{VS} / \mathrm{mg} \mathrm{NO}_{3}-\mathrm{N}$.
\end{abstract}

Keywords: biodenitrification, slow sand filtration, drinking water

\section{Introduction}

Nitrate contamination in groundwater arises from agricultural practices and improper discharge of industrial and municipal wastes. Accumulation of various forms of nitrogen in water can lead to adverse effects including depletion of dissolved oxygen in receiving waters, ammonia toxicity to aquatic life, and public health problems related to the presence of nitrate in drinking water supplies (Elefsiniotis and Li, 2006).

Regulations for drinking water are required in order to limit human risks and environmental pollution for $\mathrm{NO}_{3}-\mathrm{N}$ and $\mathrm{NO}_{2}-\mathrm{N}$ in drinking water. While the United States Environmental Protection Agency (USEPA) has set maximum contaminant level goal (MCLG) of $10 \mathrm{mg} \mathrm{NO}-\mathrm{N}$ and $1.0 \mathrm{mg} \mathrm{NO}-\mathrm{N} / \ell$, the World Health Organisation (WHO, 1984) and European Economic Community (EU, 1998) have set standards of $11.3 \mathrm{mg} \mathrm{NO}_{3}-\mathrm{N} / \ell$ and $0.03 \mathrm{mg} \mathrm{NO}-\mathrm{N} / \ell$.

It is necessary to reduce $\mathrm{NO}_{3}-\mathrm{N}$ from drinking water supplies for human consumption when the $\mathrm{NO}_{3}-\mathrm{N}$ concentration exceeds the drinking water standards. Among the various $\mathrm{NO}_{3}$ $\mathrm{N}$ removal methods such as ion exchange, biodenitrification, reverse osmosis, electrodialysis and distillation, biological processes have been shown to be more efficient and convenient.

The slow sand filter (SSF) has been known to be a simple to operate, low cost, efficient and reliable technique and has been used successfully to remove micro-organisms in drinking water since 1900. It has been well documented in the literature for many decades. In conventional water treatment works, SSF

\footnotetext{
* To whom all correspondence should be addressed.

용 +90 346219 10 10/1296; fax: +90 34621911 77;

e-mail:saslan@,cumhuriyet.edu.tr

Received 21 July 2006; accepted in revised form 11 November 2007.
}

is generally the third stage of water treatment purification after reservoir storage and rapid filtration, prior to disinfection (Ellis, 1985). However, SSF can also provide a single-stage treatment for raw waters within certain water quality limits of turbidity and algal content (Bowles et al., 1983). Simplicity, low capital cost, and operating costs are other principal advantages of SSF compared with more sophisticated methods of water treatment (Campos et al., 2002). Among the more important mechanisms for the removal of contaminants in water through SSF are: biological activity at the upper layer of the filter, adsorption, mechanical filtration, and surface catalysed degradation. These process features make SSF most attractive for advanced treatment of effluents (Adin, 2003). Recent attention has focused on the use of SSFs for tertiary wastewater treatment (Nakhla and Farooq, 2003). The SSF was operated in drinking and wastewater treatment for removal of carbon and nitrification (Rodgers et al., 2005), pathogenic bacteria (Bomo et al., 2003), protozoan parasite (Timms et al., 1995), and suspended solids (Christopherson et al., 2005; Aslan, 2005; Aslan and Turkman 2006; Rocca et al., 2005). The SSF was applied to remove nitrogen in wastewater using biological nitrification and denitrification (Nakhla and Farooq, 2003).

Although the SSF has been applied for the removal of pathogens, suspended solids and organics in wastewater, very few studies have been conducted on the treatment of $\mathrm{NO}_{3}-\mathrm{N}$ removal in drinking water. The objective of this study is to present experimental data on the biological removal of $\mathrm{NO}_{3}-\mathrm{N}$ through the SSF depths operating at various filtration rates under laboratory conditions.

\section{Materials and methods}

The SSF was inoculated with micro-organisms taken from the aeration basin at Cumhuriyet University Wastewater Treatment 
Plant in Sivas, Turkey, acclimatised to ethanol and $\mathrm{NO}_{3}-\mathrm{N}$ with medium solution prepared daily in distilled water. The inoculation lasted about one month for microbial growth with daily replenishment of $\mathrm{NO}_{3}-\mathrm{N}$ and ethanol in medium solution in a $500 \mathrm{~m} \ell$ bottle.

\section{Batch experiments}

Batch experiments were carried out to determine the optimal carbon to nitrogen $(\mathrm{C} / \mathrm{N})$ ratio for microbial activity. Experiments were performed in $500 \mathrm{~m} \ell$ glass bottles containing medium solutions. $\mathrm{C} / \mathrm{N}$ ratios varied from 1.1 to 3.0 for $\mathrm{C}$ using ethanol while the $\mathrm{NO}_{3}-\mathrm{N}$ concentration was kept constant at $22.6 \mathrm{mg} / \ell$. Acclimated micro-organisms were added into the flasks and cultures were placed on a shaking incubator at $30^{\circ} \mathrm{C}$ at $100 \mathrm{r} / \mathrm{min}$. $\mathrm{NO}_{3}-\mathrm{N}, \mathrm{NO}_{2}-\mathrm{N}$, and chemical oxygen demand (COD) analyses were performed in the feed solution and in the clear samples at the end of the reaction.

\section{Experimental set-up of the biological SSF}

The biological SSF experimental set-up consisted of a cylindrical stainless steel biological reactor, $10 \mathrm{~cm}$ inner diameter and $100 \mathrm{~cm}$ height, completely submerged and operating in down flow mode (Fig. 1). The filter was equipped with 6 water sampling and effluent ports. Screens were placed at the bottom and sampling ports of the filter to prevent clogging of the column outlet.

The synthetic medium solution was stored in $30 \ell$ plastic containers of $\mathrm{C}$ and $\mathrm{NO}_{3}-\mathrm{N}$ sources including trace elements at room temperature $\left(17 \pm 3^{\circ} \mathrm{C}\right)$. The outer surfaces of the containers and tubes were wrapped with aluminium foil to prevent algal growth. $\mathrm{NO}_{3}-\mathrm{N}$ and $\mathrm{C}$ concentration in the containers were measured periodically throughout the experimental study. A piston pump was used to transfer synthetic medium solutions to the SSF. Transfer tubes were washed with acidic solution weekly to prevent microbial growth.

The filter column was filled with filter sand of an effective diameter of $0.5 \mathrm{~mm}$ and uniformity coefficient of 1.23 . The SSF had a liquid volume $2 \ell$ after packing sand and $5 \mathrm{~cm}$ water depth on the top of the filter was maintained throughout the experiment. The sand was washed several times to remove impurities before packing the filter.

The filter was operated at filtration rates between 0.02 to $0.120 \mathrm{~m} / \mathrm{h}$ and 0.01 to $0.25 \mathrm{~m} / \mathrm{h}$ with concentrations of 22.6 and $45.2 \mathrm{mg} \mathrm{NO}-\mathrm{N} / \ell$, respectively, and effluent samples of the sand filter were taken at 6 depths of 10,15,20,40,60, $80 \mathrm{~cm}$, and the bottom. The nitrogen loading rate (NLR) was varied by increasing the influent flow rate. The flow rate was adjusted by a valve at the bottom of the filter. The operational condition of the SSF system is summarised at Table 1. Manometers were installed at each sampling ports to measure head loss. The filter was operated primarily to assess the impact of filtration rates and filter depths on the $\mathrm{NO}_{3}-\mathrm{N}$ removal performance.

Prior to operation, the SSF was filled with synthetic medium solution and $10 \mathrm{~m} \ell$ inoculated micro-organisms in the batch unit was added to the upper layer of the filter. The inoculation of the SSF was carried out at the lowest filtration rate $(0.01 \mathrm{~m} / \mathrm{h})$ and the filter effluent was withdrawn daily at the bottom of the filter to monitor the performance by measuring $\mathrm{NO}_{3}-\mathrm{N}, \mathrm{NO}_{2}-\mathrm{N}$, and $\mathrm{C}$ concentration throughout the acclimation period. After about $3 \mathrm{~d}$, effluent $\mathrm{NO}_{3}-\mathrm{N}$ concentration started to decrease and complete $\mathrm{NO}_{3}-\mathrm{N}$ removal was achieved after $15 \mathrm{~d}$ of stable operation of the SSF.

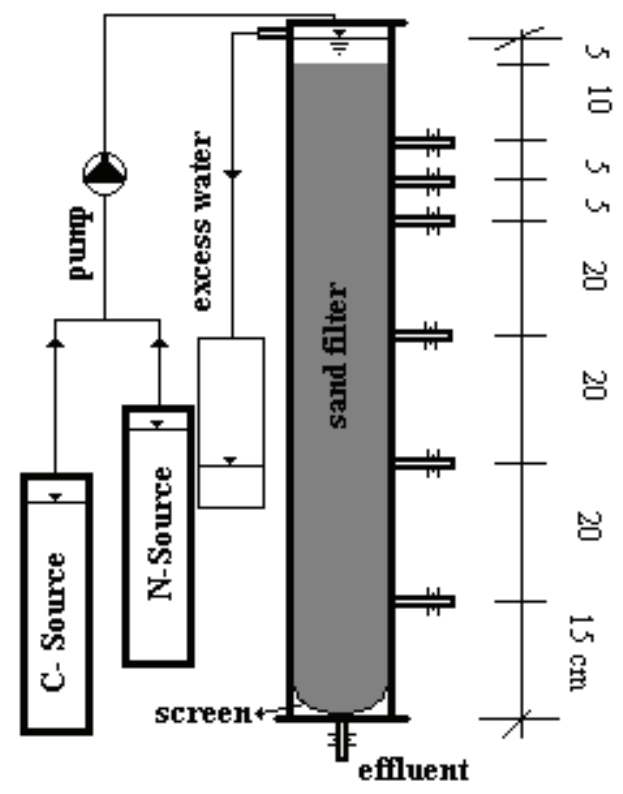

Figure 1

Schematic representation of the biological SSF experimental set-up

TABLE 1

\begin{tabular}{|c|c|c|c|}
\hline \multicolumn{4}{|c|}{$\begin{array}{c}\text { TABLE } 1 \\
\text { Operational condition of the SSF system }\end{array}$} \\
\hline $\begin{array}{l}\text { Inlet } \mathrm{NO}_{3}-\mathrm{N} \\
\text { concentration }\end{array}$ & $\begin{array}{l}\text { Velocity } \\
(\mathrm{m} / \mathrm{h})\end{array}$ & $\begin{array}{c}\text { Nitrogen } \\
\text { loading rate } \\
\left(\mathrm{g} \mathrm{N} / \mathrm{m}^{3} \cdot \mathrm{d}\right)\end{array}$ & $\begin{array}{c}\text { Surface } \\
\text { loading rate } \\
\text { (g N/m².d) }\end{array}$ \\
\hline \multirow{6}{*}{$(22.6 \mathrm{mg} / \ell)$} & 0.02 & 11.4 & 10.8 \\
\hline & 0.03 & 17.1 & 16.3 \\
\hline & 0.055 & 31.4 & 29.8 \\
\hline & 0.07 & 40 & 38 \\
\hline & 0.1 & 57.1 & 54.2 \\
\hline & 0.12 & 68.5 & 65.1 \\
\hline \multirow{7}{*}{$(45.2 \mathrm{mg} / \ell)$} & 0.01 & 11.4 & 10.8 \\
\hline & 0.02 & 22.8 & 21.7 \\
\hline & 0.055 & 62.8 & 59.7 \\
\hline & 0.088 & 100.5 & 95.5 \\
\hline & 0.18 & 205.5 & 195.3 \\
\hline & 0.2 & 228.3 & 217 \\
\hline & 0.25 & 285.4 & 271.2 \\
\hline
\end{tabular}

When the flow rate through the filter could not be maintained and the head loss reached $20 \mathrm{~cm}$, the water layer above the sand bed was drained and $2 \mathrm{~cm}$ depth of the top layer of the filter scraped out to remove micro-organisms in the sand. Volatile solids (VS) measurement was carried out on the removed sand. After scraping and cleaning the sand, the upper layer of the filter was filled with clean sand, and the filter was operated for at least $3 \mathrm{~d}$ to promote microbial growth at the top of the filter until achieving higher than $90 \% \mathrm{NO}_{3}-\mathrm{N}$ removal at the bottom of the filter.

SSF was operated at room temperature. After completing the first experiment at $22.6 \mathrm{mg} \mathrm{NO}-\mathrm{N} / \ell, 10 \mathrm{~cm}$ depth of upper layer of the filter was scrapped out, the concentrations of VS onto the sand was measured and then clean sand was replaced onto the filter. $\mathrm{NO}_{3}-\mathrm{N}$ concentration of the synthetic medium solution after mixing with $\mathrm{C}$ solution was increased to 45.2 $\mathrm{mg} / \ell$ while maintaining the $\mathrm{C} / \mathrm{N}$ ratio at 1.5 during the second step. 


\section{Synthetic medium composition}

The liquid medium used consisted of a mineral base supplemented with $\mathrm{NO}_{3}-\mathrm{N}$ as sole electron acceptor and ethanol as electron donor. The medium constituents were $\mathrm{KNO}_{3}$, ethanol, $\mathrm{KH}_{2} \mathrm{PO}_{4}(150 \mathrm{mg} / \ell)$, and $\mathrm{NaHCO}_{3}(325 \mathrm{mg} / \ell)$. This medium was supplemented with $1 \% \mathrm{v} / \mathrm{v}$ of a solution containing $\mathrm{FeSO}_{4} \cdot 7 \mathrm{H}_{2} \mathrm{O}$ $(0.20 \mathrm{mg} / \ell)$, titriplex $(0.565 \mathrm{mg} / \ell)$, and with $0.1 \% \mathrm{v} / \mathrm{v}$ of a trace nutrient solution containing $\mathrm{ZnSO}_{4} .7 \mathrm{H}_{2} \mathrm{O}(0.1 \mathrm{~g} / \ell), \mathrm{MnCl}_{2} .4 \mathrm{H}_{2} \mathrm{O}$ $(0.03 \mathrm{~g} / \ell), \mathrm{H}_{3} \mathrm{BO}_{3}(0.3 \mathrm{~g} / \ell), \mathrm{CoCl}_{2} .6 \mathrm{H}_{2} \mathrm{O}(0.2 \mathrm{~g} / \ell), \mathrm{CuCl}_{2} .2 \mathrm{H}_{2} \mathrm{O}$ $(0.01 \mathrm{~g} / \ell), \mathrm{NiCl}_{2} \cdot 6 \mathrm{H}_{2} \mathrm{O}(0.02 \mathrm{~g} / \ell)$, and $\mathrm{NaMoO}_{4} \cdot 2 \mathrm{H}_{2} \mathrm{O}(0.03 \mathrm{~g} / \ell)$ (Aslan, 2005). The final $\mathrm{pH}$ of the medium was adjusted to 7.5 using $\mathrm{NaOH}$ solution.

\section{Analytical methods}

$\mathrm{NO}_{3}-\mathrm{N}, \mathrm{NO}_{2}-\mathrm{N}$, and $\mathrm{COD}$ concentrations of influent solutions were measured routinely. Samples were withdrawn daily from 6 effluent points and the bottom of the SSF and centrifuged at $6000 \mathrm{r} / \mathrm{min}$ for $30 \mathrm{~min}$ to remove suspended solids from the effluent. $\mathrm{NO}_{3}-\mathrm{N}, \mathrm{NO}_{2}-\mathrm{N}$, and $\mathrm{COD}$ analyses were performed with clear samples and $\mathrm{pH}$ was measured. Biomass concentrations were determined as VS by scraping a $2 \mathrm{~cm}$ deep layer of sand off the SSF. The sand was then washed gently in distilled water and VS were measured in $50 \mathrm{~m} \ell$ eloquent and the sand was placed back onto the sand filter. COD concentrations of the influent and effluent samples and the VS were determined according to Standard Methods (1995) and C concentrations were calculated according to its stoichiometric relationship with $\mathrm{COD}$ for ethanol. $\mathrm{NO}_{3}-\mathrm{N}$ and $\mathrm{NO}_{2}-\mathrm{N}$ were analysed with the Merck photometer Nova 60 using analytical kits; $\mathrm{NO}_{2}-\mathrm{N}$ (14776), and $\mathrm{NO}_{3}-\mathrm{N}$ (14773).

\section{Results and discussion}

\section{Determination of optimum $\mathrm{C} / \mathrm{N}$ ratio in batch units}

The temperature affects the removal rate of $\mathrm{NO}_{3}-\mathrm{N}$ and the microbial growth rate. About complete $\mathrm{NO}_{3}-\mathrm{N}$ removal was observed at temperature between 22 and $37^{\circ} \mathrm{C}$ (Aslan and Turkman, 2004). Because of this reason, batch experiments were performed at $30^{\circ} \mathrm{C}$ for $3 \mathrm{~d}$ after which at least $90 \% \mathrm{NO}_{3}-\mathrm{N}$ removal efficiency was observed to obtain optimal $\mathrm{C} / \mathrm{N}$ ratio for the biological SSF system. The optimum $\mathrm{C} / \mathrm{N}$ ratio was assumed to be the ratio which allowed achieving maximum removal of $\mathrm{NO}_{3}-\mathrm{N}$ with minimum excess $\mathrm{C}$ in the effluent.

It can be seen in Fig. 2 that the low $\mathrm{C} / \mathrm{N}$ ratio resulted in low $\mathrm{NO}_{3}-\mathrm{N}$ removal efficiency and high $\mathrm{NO}_{3}-\mathrm{N}$ level at the end of the reaction. Optimum $\mathrm{C} / \mathrm{N}$ ratio was found to be 1.5 when using ethanol in batch tests. At $\mathrm{C} / \mathrm{N}$ ratios below the optimum ratio, the $\mathrm{NO}_{3}-\mathrm{N}$ removal was found to be dependent upon the $\mathrm{C}$ concentrations, causing a noticeable fall of $\mathrm{NO}_{3}-\mathrm{N}$ removal in batch units. Although no significant improvement in $\mathrm{NO}_{3}-\mathrm{N}$ removal was observed with the $\mathrm{C} / \mathrm{N}$ ratio in excess of the optimum value, excess amount of $\mathrm{C}$ remained in the water. The $\mathrm{C}$ consumption reported here is in the range of the values obtained by Richard (1989) and is about the same as the values reported by Delanghe et al. (1994) and Aslan
(2005), but is $50 \%$ higher than the values given by the Dahab and Sirigina (1994).

Since the low $\mathrm{C} / \mathrm{N}$ ratio $(\mathrm{C} / \mathrm{N}<1.5)$ of the influent caused incomplete denitrification, the accumulation of $\mathrm{NO}_{2}-\mathrm{N}$ occurred and the $\Delta \mathrm{C} / \Delta \mathrm{N}$ ratio was higher than 4.0. The highest $\Delta \mathrm{C} / \Delta \mathrm{N}$ ratio was observed for 1.2 of the $\mathrm{C} / \mathrm{N}$ ratio.

\section{SSF experimental results}

The SSF was operated at low velocity at the start of the experiments to promote microbial growth through the filter bed and $\mathrm{NO}_{3}-\mathrm{N}, \mathrm{NO}_{2}-\mathrm{N}$ and $\mathrm{C}$ concentrations in the effluent were measured during this stage. After $15 \mathrm{~d}$ of operation, $\mathrm{NO}_{3}-\mathrm{N}$ was not detected in the filter effluent.

The filtration rate was brought to 0.02 and $0.01 \mathrm{~m} / \mathrm{h}$ (about 0.16 and $0.08 \mathrm{\ell} / \mathrm{h}$ ) during the initial runs and was then progressively increased to $0.12(0.94 \mathrm{\ell} / \mathrm{h})$ and $0.25 \mathrm{~m} / \mathrm{h}(2 \mathrm{\ell} / \mathrm{h})$ for 22.6 and $45.2 \mathrm{mg} \mathrm{NO}_{3}-\mathrm{N} / \ell$ concentrations, respectively. The filter was operated at $45.2 \mathrm{mg} / \ell$ influent $\mathrm{NO}_{3}-\mathrm{N}$ concentration to achieve maximum NLR.

\section{First step $\mathrm{NO}_{3}-\mathrm{N}$ removal through the $\mathrm{SSF}$}

$\mathrm{NO}_{3}-\mathrm{N}$ concentration was kept at $22.6 \mathrm{mg} / \ell$ during the first step of the study. Most of the $\mathrm{NO}_{3}-\mathrm{N}$ removal was observed at the upper layer of the $10 \mathrm{~cm}$ filter bed. $\mathrm{NO}_{3}-\mathrm{N}, \mathrm{NO}_{2}-\mathrm{N}$, and $\mathrm{C}$ were not detected in the effluent port and the $60 \mathrm{~cm}$ depth of the SSF throughout the first step of the study. Although increasing filtration rate increased $\mathrm{NO}_{3}-\mathrm{N}, \mathrm{NO}_{2}-\mathrm{N}$, and $\mathrm{C}$ concentrations, $\mathrm{NO}_{3}-\mathrm{N}$ concentration was still below the acceptable level for the drinking water at the $0.02,0.03,0.055$, and $0.07 \mathrm{~m} / \mathrm{h}$ filtration rates at $10 \mathrm{~cm}$ filter depth and the 0.1 and $0.12 \mathrm{~m} / \mathrm{h}$ filtration rates at $15 \mathrm{~cm}$ filter depth (Fig. 3).

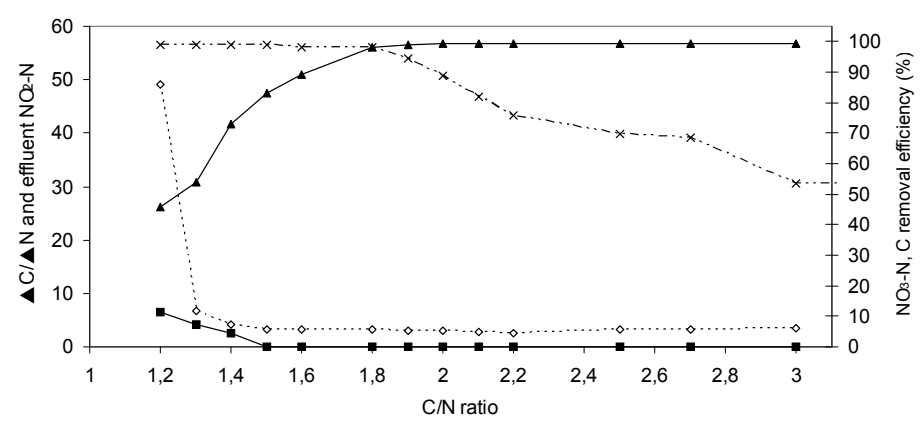

Figure 2

Effect of various $\mathrm{C} / \mathrm{N}$ ratios on $\mathrm{NO}_{3}-\mathrm{N}$ and $\mathrm{C}$ removal $\checkmark \Delta \mathrm{C} / \Delta \mathrm{N} ;=\mathrm{NO}_{2}-\mathrm{N} ; \mathbf{\Delta} \mathrm{NO}_{3}-\mathrm{N} ; \times \mathrm{C}(\%)$

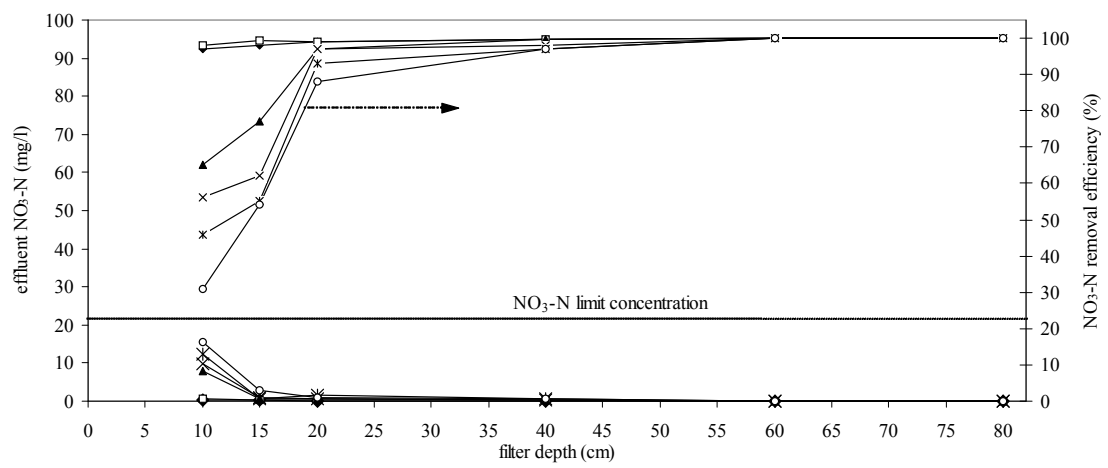

Figure 3

Effluent $\mathrm{NO}_{3}-\mathrm{N}$ concentrations and $\mathrm{NO}_{3}-\mathrm{N}$ removal efficiency throughout the $\mathrm{SSF}$ at various loading rates (influent concentration $22.6 \mathrm{mg} \mathrm{NO}{ }_{3}-\mathrm{N} / \mathrm{l}$ )

- $0.02 \square 0.03 \wedge 0.055 \times 0.07 \times 0.1 \circ 0.12 \mathrm{~m} / \mathrm{h}$ 
The filtration rates varied from 0.02 and $0.03 \mathrm{~m} / \mathrm{h}$, corresponding to an overall average $\mathrm{NO}_{3}-\mathrm{N}$ removal efficiency of $98 \%$ at $10 \mathrm{~cm}$ filter depth. Increasing filtration rates to $0.055,0.07,0.1$, and $0.12 \mathrm{~m} / \mathrm{h}$, the removal efficiencies of $\mathrm{NO}_{3}-\mathrm{N}$ decreased to 65 , 56,46 , and $31 \%$, respectively at the first sampling port.

Lower $\mathrm{NO}_{3}-\mathrm{N}$ concentration was observed for the filtration rates between 0.02 to $0.07 \mathrm{~m} / \mathrm{h}$ than the standard limit of $10 \mathrm{mg}$ $\mathrm{NO}_{3}-\mathrm{N} / \ell$. Effluent $\mathrm{NO}_{3}-\mathrm{N}$ concentrations ranged from 12.2 to $15.6 \mathrm{mg} / \ell$ at the filtration rates of 0.1 and $0.12 \mathrm{~m} / \mathrm{h}$ at the $10 \mathrm{~cm}$ filter depth and decreased to 0.5 and $2.8 \mathrm{mg} \mathrm{NO}_{3}-\mathrm{N} / \ell$, respectively at the $15 \mathrm{~cm}$ depth. Accordingly, about 22 and $7 \mathrm{mg} \mathrm{NO}_{3}$ $\mathrm{N} / \ell$ were removed at the filter depth of $10 \mathrm{~cm}$ at filtration rates between 0.02 and $1.2 \mathrm{~m} / \mathrm{h}$, respectively, and the remaining were removed at higher depths.

The intermediate product $\mathrm{NO}_{2}-\mathrm{N}$ of denitrification in the effluent water at the $40 \mathrm{~cm}$ filter depth did not exceed the maximum limit value of $0.03 \mathrm{mg} \mathrm{NO}$ $\mathrm{N} / \ell$ at the filtration rate of $0.07 \mathrm{~m} / \mathrm{h}$. $\mathrm{NO}_{2}-\mathrm{N}$ distributions through the $\mathrm{SSF}$ are given in Fig. 4. The effluent $\mathrm{NO}_{2}-\mathrm{N}$ concentrations were $0.26,0.18,0.05 \mathrm{mg} / \ell$, and lower than the detection limit at the $10,15,20$, and $40 \mathrm{~cm}$ filter depths at 0.02 $\mathrm{m} / \mathrm{h}$ filtration rate. Increasing filtration rate from 0.02 to $0.12 \mathrm{~m} / \mathrm{h}$ increased the effluent $\mathrm{NO}_{2}-\mathrm{N}$ concentration at the effluent point. Although, effluent samples at the $40 \mathrm{~cm}$ depth contained more than $0.03 \mathrm{mg} \mathrm{NO}{ }_{2}-\mathrm{N} / \ell$ at the filtration rates of between 0.07 and $1.2 \mathrm{~m} / \mathrm{h}, \mathrm{NO}_{2}-\mathrm{N}$ was not detected beyond the $40 \mathrm{~cm}$ depth.

The $\mathrm{C}$ content of the filtrate was high at the top layer and decreased gradually through the SSF (Fig. 5). The C outlet concentration was decreased through the filter depth and it was not detected beyond the $40 \mathrm{~cm}$ filter depth. The effluent $\mathrm{C}$ concentrations were 7.2, 5.9, 5.3, and 2.1 $\mathrm{mg} / \ell$ at $10,15,20$, and $40 \mathrm{~cm}$ filter depths at $0.02 \mathrm{~m} / \mathrm{h}$ filtration rate. The effluent $\mathrm{C}$ concentrations varied between about 47 and $9 \mathrm{mg} / \ell$ at the top of the filter and $40 \mathrm{~cm}$ filter depth at $0.12 \mathrm{~m} / \mathrm{h}$ filtration rate, respectively.

\section{Second step $\mathrm{NO}_{3}-\mathrm{N}$ removal through the SSF}

As expected, increasing the $\mathrm{NO}_{3}-\mathrm{N}$ concentration in the medium solution increased the $\mathrm{NO}_{3}-\mathrm{N}, \mathrm{NO}_{2}-\mathrm{N}$, and $\mathrm{C}$ concentrations in the effluent. The $\mathrm{NO}_{3}-\mathrm{N}$ removal efficiency was $87 \%$ at the filtration rate of $0.01 \mathrm{~m} / \mathrm{h}$ at the $10 \mathrm{~cm}$ depth and increased to $99 \%$ at the $20 \mathrm{~cm}$ and $\mathrm{NO}_{3}-\mathrm{N}$ was not detected beyond the 20 $\mathrm{cm}$ depth. $\mathrm{NO}_{3}-\mathrm{N}$ concentrations were higher than the standard limit of $10 \mathrm{mg}$ $\mathrm{NO}_{3}-\mathrm{N} / \ell$ for the filtration rates higher than $0.02 \mathrm{~m} / \mathrm{h}$ at the $10 \mathrm{~cm}$ depth of and complete $\mathrm{NO}_{3}-\mathrm{N}$ removal was observed at filtration rates lower than $0.2 \mathrm{~m} / \mathrm{h}$ at the $60 \mathrm{~cm}$ depth (Fig. 6).
Increasing filtration rates above $0.055 \mathrm{~m} / \mathrm{h}$ had little effect on the effluent concentration of $\mathrm{NO}_{3}-\mathrm{N}$ at the $10 \mathrm{~cm}$ filter depth. At the highest filtration rate, $\mathrm{NO}_{3}-\mathrm{N}$ removal efficiencies were between 39 and $95 \%$ through filter depths. When the SSF was operated at high filtration rate, the short contact time caused low $\mathrm{NO}_{3}-\mathrm{N}$ removal. Beyond the filter depth of $60 \mathrm{~cm}, \mathrm{NO}_{3}-\mathrm{N}$ removal was not observed for the filtration rates of 0.2 and 0.25 $\mathrm{m} / \mathrm{h}$; however, $\mathrm{NO}_{3}-\mathrm{N}$ concentration was lower than the standard value.

Although relatively high concentrations of $\mathrm{NO}_{2}-\mathrm{N}$ were observed at the $10 \mathrm{~cm}$ filter depth, $\mathrm{NO}_{2}-\mathrm{N}$ was decreased through the filter, except at the highest filtration rate. However, at this rate a concentration of $8.4 \mathrm{mg} \mathrm{NO}-\mathrm{N}$ was detected in the

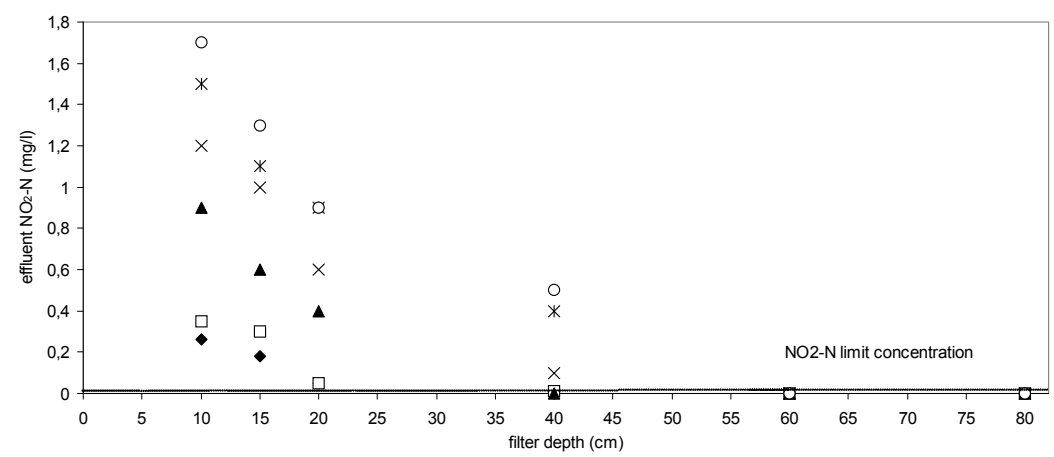

Figure 4

Effluent $\mathrm{NO}_{2}-\mathrm{N}$ concentration throughout the $\mathrm{SSF}$ at various loading rates (influent concentration $22.6 \mathrm{mg} \mathrm{NO}-\mathrm{N} / \mathrm{l}$ )

$\bullet 0.02 \square 0.03 \Delta 0.055 \times 0.07 \ll 0.1 \circ 0.12 \mathrm{~m} / \mathrm{h}$

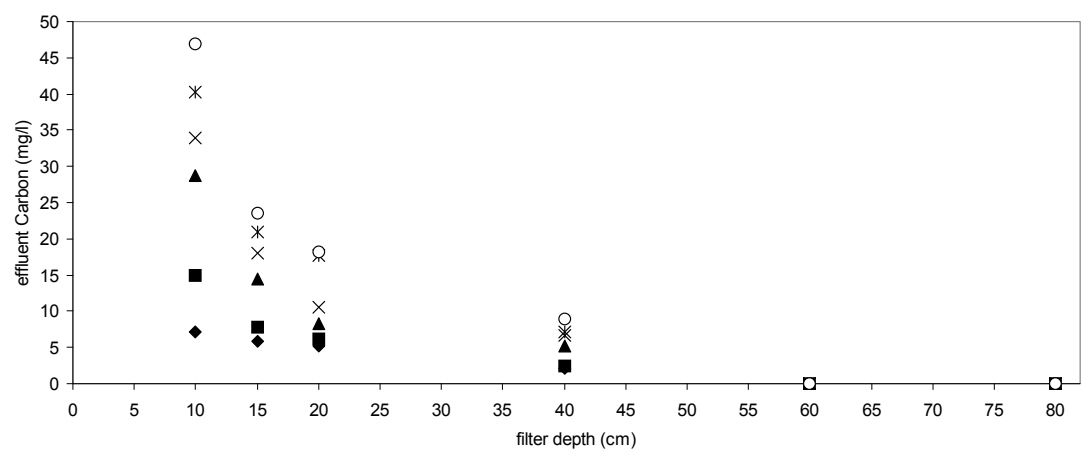

Figure 5

Effluent $C$ concentration throughout the SSF at various loading rates (influent concentration $22.6 \mathrm{mg} \mathrm{NO}-\mathrm{N} / \mathrm{l}$ ) • $0.02 \square 0.03 \Delta 0.055 \times 0.07 \leqslant 0.1 \circ 0.12 \mathrm{~m} / \mathrm{h}$

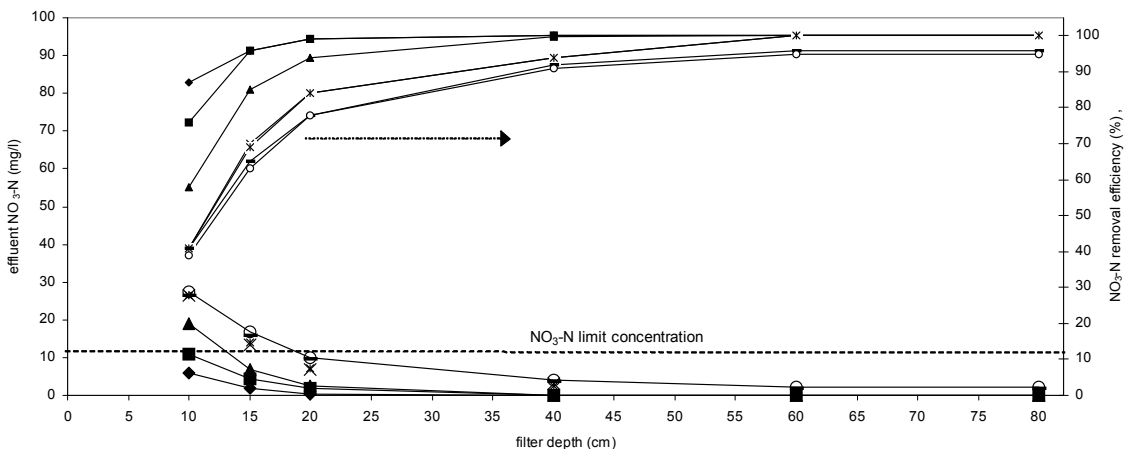

Figure 6

Effluent $\mathrm{NO}_{3}-\mathrm{N}$ concentrations and $\mathrm{NO}_{3}-\mathrm{N}$ removal efficiency throughout the SSF at various loading rates (influent concentration $45.2 \mathrm{mg} \mathrm{NO}_{3}-\mathrm{N} / \mathrm{t}$ ) - 0.01; - 0.02; $\boldsymbol{\Delta}$ 0.055; X 0.08; «0.18; - 0.12; $0.25 \mathrm{~m} / \mathrm{h}$ 
effluent, which was higher than the limit value (Fig. 7).

The $\mathrm{C}$ source was entirely consumed in the SSF when the filtration rate was low, but more than $5 \mathrm{mg} / \ell \mathrm{C}$ remained in the effluent at the filtration rate of 0.2 and $0.25 \mathrm{~m} / \mathrm{h}$. $\mathrm{C}$ concentrations were between 54 and 125 $\mathrm{mg} / \ell$ at the $10 \mathrm{~cm}$ filter depth at the filtrations rates applied during the study (Fig. 8).

In this study, more than $95 \% \mathrm{NO}_{3}-\mathrm{N}$ removal efficiency was achieved at the filtration rate of $0.25 \mathrm{~m} / \mathrm{h}$ at the depth of 60 $\mathrm{cm}$; by comparison, Nakhla and Faroog (2003) achieved about $80 \%$ denitrification efficiency in raw wastewater using the $\mathrm{SSF}$ at a depth of $80 \mathrm{~cm}$, while $95 \% \mathrm{NO}_{3}-\mathrm{N}$ removal was obtained at the filter depth of $40 \mathrm{~cm}$ at a filtration rate of $0.18 \mathrm{~m} / \mathrm{h}$. The SSF was performed as a post-treatment after the biological process and it was assumed that the slowly biodegradable soluble COD in the wastewater might slow down the denitrification process. Aslan (2005), Aslan and Turkman (2005 and 2006) results indicated that about $20 \%$ of the $\mathrm{NO}_{3}-\mathrm{N}$ remaining from the biological denitrification reactor was removed in the following sand filter at a depth of $30 \mathrm{~cm}$. Because the SSF was operated at a high flow rate $(0.125 \mathrm{~m} / \mathrm{h})$ and low $\mathrm{C}$ content of the influent water, $\mathrm{NO}_{3}-\mathrm{N}$ removal was lower than in this study.

The SSF showed good $\mathrm{NO}_{3}-\mathrm{N}$ removal performance at the $10 \mathrm{~cm}$ filter depth with daily removal of 28.2 and $50 \mathrm{~g} \mathrm{NO}_{3}-\mathrm{N} / \mathrm{m}^{3}$ at a filtration rate 0.02 and $0.01 \mathrm{~m} / \mathrm{h}$ when influent concentrations were 22.6 and $45.2 \mathrm{mg} / \ell$, respectively. Daily removal decreased, with increasing filtration rates and depths, because most of the $\mathrm{NO}_{3}-\mathrm{N}$ was removed at the upper layer of the SSF (Figs. 9 and 10).

In this study, the occurrence of the highest microbial activities in the top layer (0-40 cm filter depth) of the SSF was observed and beyond this depth significant microbial activity did not occur.

Complete $\mathrm{NO}_{3}-\mathrm{N}$ removal was obtained with influent concentration of $22.6 \mathrm{mg} \mathrm{NO}$ $\mathrm{N} / \ell$. The maximum $\mathrm{NO}_{3}-\mathrm{N}$ removal rate during this period was $68.5 \mathrm{~g} / \mathrm{m}^{3} \cdot \mathrm{d}$ and about complete $\mathrm{NO}_{3}-\mathrm{N}$ removal was obtained at the $40 \mathrm{~cm}$ filter depth. Increasing the NLR from 68.5 to $285 \mathrm{~g} / \mathrm{m}^{3} \cdot \mathrm{d}$ (surface loading rate $171.2 \mathrm{~g} / \mathrm{m}^{2} \cdot \mathrm{d}$ ) by increasing the influent flow rate and influent $\mathrm{NO}_{3}-\mathrm{N}$ concentrations appeared to result in an incomplete denitrification.

It was evident that the process was unable to provide $\mathrm{NO}_{3}-\mathrm{N}$ removal rate of more than $228 \mathrm{~g} \mathrm{NO}_{3}-\mathrm{N} / \mathrm{m}^{3} \cdot \mathrm{d}(0.2 \mathrm{~m} / \mathrm{h}$ flow rate $)$. Although the $\mathrm{NO}_{3}-\mathrm{N}$ removal efficiency dropped slightly from 96 to $95 \%$ when the NLR increased from 228 to $285 \mathrm{~g} \mathrm{NO}_{3} / \mathrm{m}^{3} \cdot \mathrm{d}$, the effluent water contained a higher con-

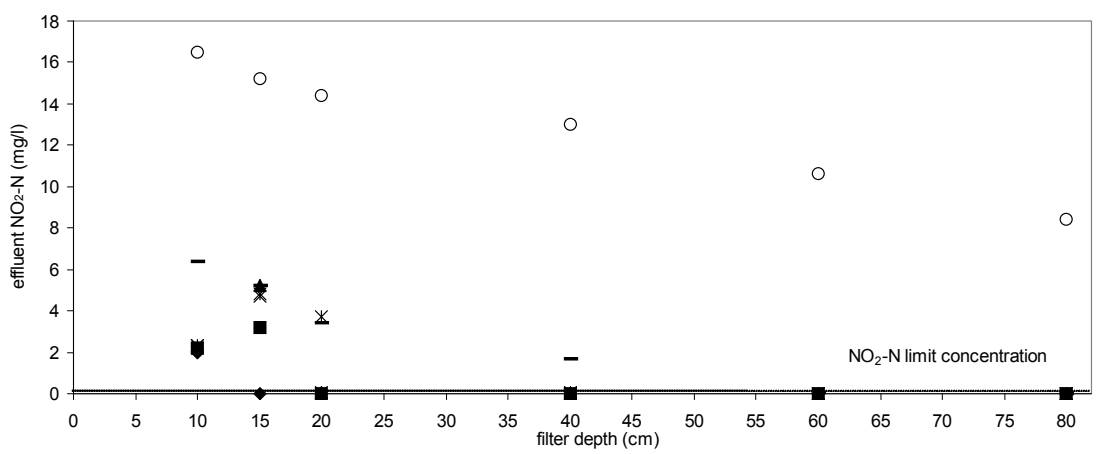

Figure 7

Effluent $\mathrm{NO}_{2}-\mathrm{N}$ concentration throughout the SSF at various loading rates (influent concentration $45.2 \mathrm{mg} \mathrm{NO}_{3}-\mathrm{N} / \mathrm{l}$ ) - 0.01; - 0.02; $\triangle 0.055 ; \times 0.08 ; \aleph 0.18 ;-0.12 ; \circ 0.25 \mathrm{~m} / \mathrm{h}$

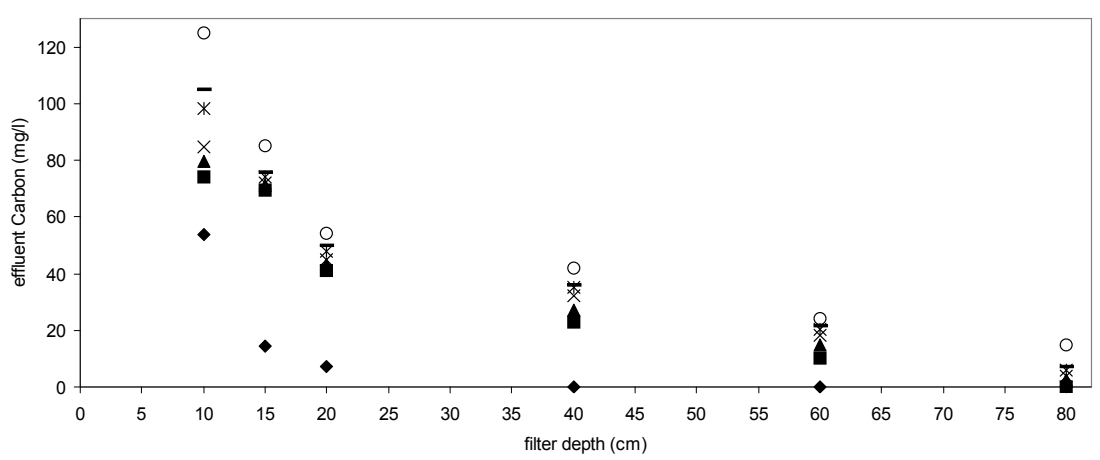

Figure 8

Effluent $\mathrm{C}$ concentration throughout the SSF at various loading rate (influent concentration $45.2 \mathrm{mg} \mathrm{NO}-\mathrm{N} / \mathrm{l}$ )

- 0.01; - 0.02; $\triangle 0.055 ; \times 0.08 ; \aleph 0.18 ;-0.12 ; \circ 0.25 \mathrm{~m} / \mathrm{h}$
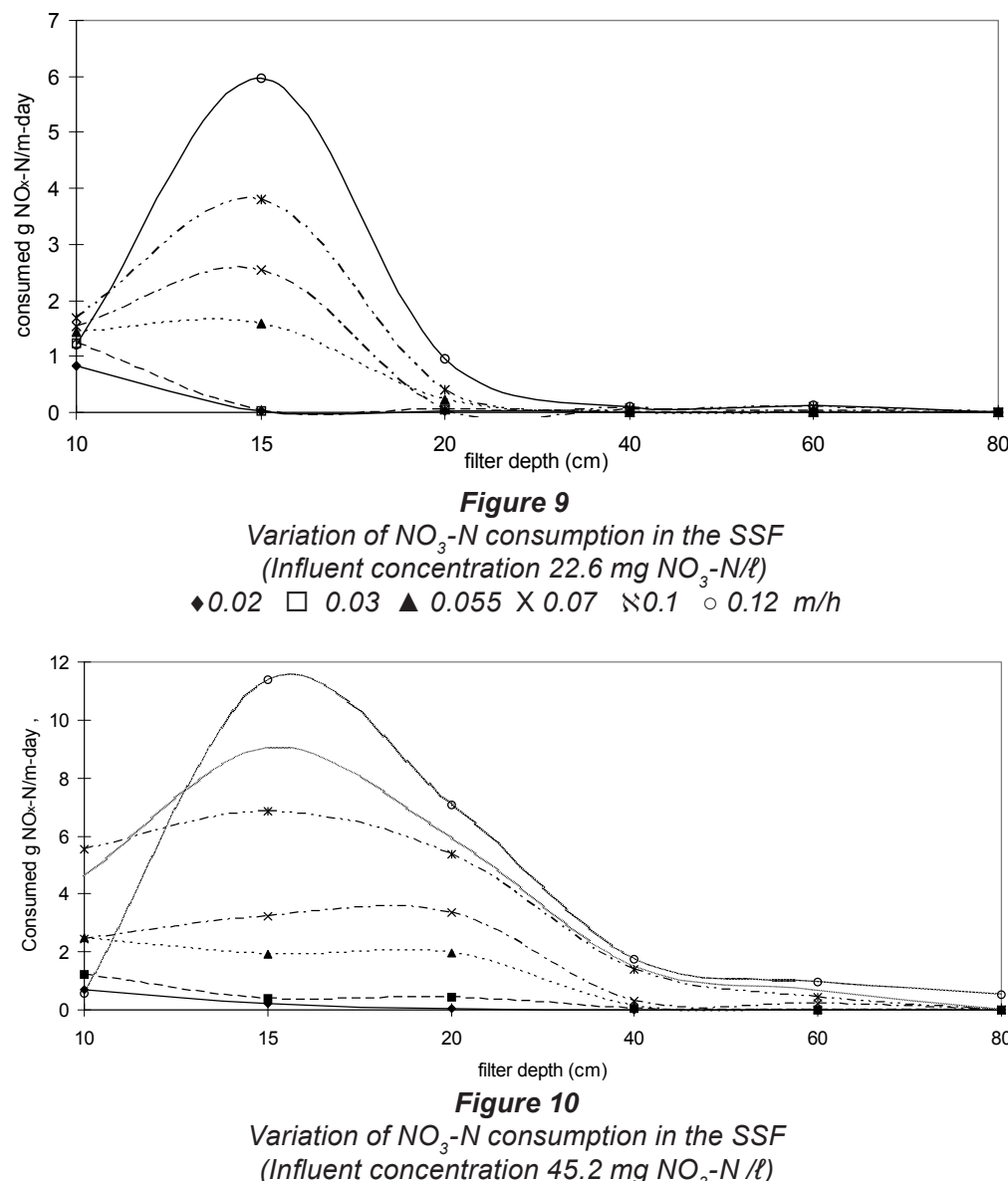


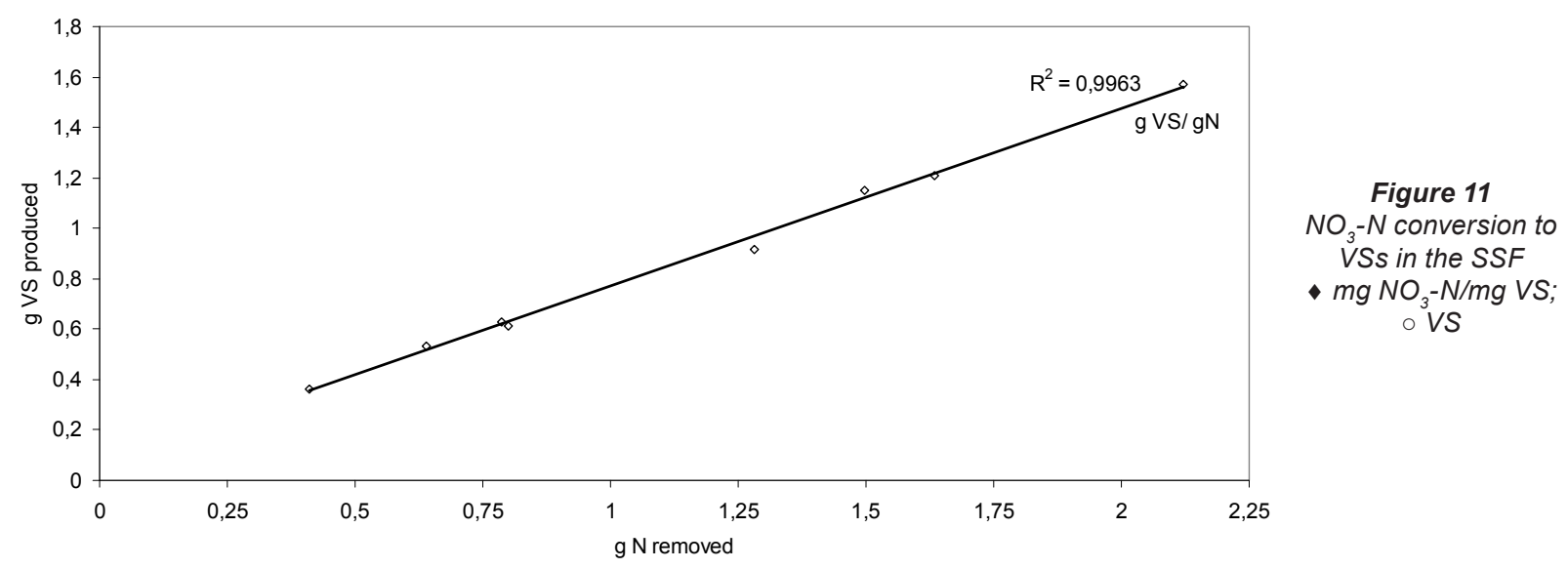

centration of $\mathrm{NO}_{2}-\mathrm{N}(8.4 \mathrm{mg} / \ell)$ than the standard value.

Alkalinity is produced during the conversion of $\mathrm{NO}_{3}-\mathrm{N}$ to nitrogen gas resulting in an increase in effluent $\mathrm{pH}$. Throughout the experimental study, because of the denitrification process the final $\mathrm{pH}$ at the effluent was slightly higher than initial $\mathrm{pH}$ and in the range of 7.8-8.1.

When the flow rate through the filter could not be maintained, VS was measured by scraping the upper layer of the filter. The biomass yield was calculated for the top layer of the SSF by considering the nitrogen consumption: calculated by using the following equation:

Nitrogen consumption $(\mathrm{mg})=$ treated water volume $(\ell) \mathrm{x}$ total nitrogen (influent - effluent from the top layer) $(\mathrm{mg} / \ell)$.

Stoichiometric relationship including cell synthesis of heterotrophic denitrification with ethanol as a C source has been suggested by Mateju et al. (1992) as:

$$
\begin{aligned}
& 0.613 \mathrm{C}_{2} \mathrm{H}_{5} \mathrm{OH}+\mathrm{NO}_{3}^{-} \rightarrow 0.10 \mathrm{C}_{5} \mathrm{H}_{7} \mathrm{NO}_{2}+0.7124 \mathrm{CO}_{2} \\
& +0.286 \mathrm{OH}+0.98 \mathrm{H}_{2} \mathrm{O}+0.449 \mathrm{~N}_{2}
\end{aligned}
$$

where $\mathrm{C}_{5} \mathrm{H}_{7} \mathrm{NO}_{2}$ represents biological cell formula. Based on Eq. (1), the reduction of $1 \mathrm{~g} \mathrm{NO}_{3}-\mathrm{N}$ theoretically produces 0.807 $\mathrm{g}$ new cells.

The results of the SSF experiment demonstrated that the average nitrogen conversion to VS was about $0.769 \mathrm{mg} \mathrm{VS} / \mathrm{mg}$ $\mathrm{NO}_{3}-\mathrm{N}$ (Fig. 11). It was apparent that consumed $\mathrm{NO}_{3}-\mathrm{N}(\mathrm{mg})$ correlated well with conversion of nitrogen to micro-organisms which is proposed in the stoichiometric equation by Mateju et al. (1992).

The nitrogen balance throughout the SSF, considering inlet and outlet differences of $\mathrm{NO}_{3}-\mathrm{N}$ and $\mathrm{NO}_{2}-\mathrm{N}$ vs. total daily removed nitrogen showed high correlation $\mathrm{R}^{2}>0.89$ at various depth of sampling ports. The average $\mathrm{NO}_{3}-\mathrm{N}$ removal efficiency was 99.9 and $95 \%$ (Std. dev. $=3.3 \pm 1, \mathrm{n}=4$ for each NLR) at NLR of 11.4 and $285.4 \mathrm{~kg} \mathrm{NO}_{3}-\mathrm{N} / \mathrm{m}^{3} \cdot \mathrm{d}$, respectively.

\section{Conclusions}

Based on experimental results of this study, it can be concluded that SSF can be used effectively for $\mathrm{NO}_{3}-\mathrm{N}$ removal in drinking water. Most of the $\mathrm{NO}_{3}-\mathrm{N}$ was removed in the top layer of the filter. In this investigation, $\mathrm{NO}_{3}-\mathrm{N}$ concentrations were reduced from the initial concentration of $22.6 \mathrm{mg} / \ell$ to below the detection limit of $\mathrm{NO}_{3}-\mathrm{N}$ at all filtration rates, and from the initial concentration of 45.2 to $2.3 \mathrm{mg} / \ell$ at the highest filtration rate. No significant $\mathrm{NO}_{2}-\mathrm{N}$ accumulation occurred in the denitrified water at the $22.6 \mathrm{mg} \mathrm{NO}-\mathrm{N} / \ell$ influent concentration. Increasing filtration rates from 0.02 to 0.12 had no adverse effect on the filter effluent. However, $8.4 \mathrm{mg} \mathrm{NO}-\mathrm{N} / \ell$ remained in the effluent water at the highest filtration rate when influent $\mathrm{NO}_{3}-\mathrm{N}$ was $45.2 \mathrm{mg} / \ell$. The SSF was unable to provide $\mathrm{NO}_{3}-\mathrm{N}$ removal rate of more than $228 \mathrm{~g} / \mathrm{m}^{3} \cdot \mathrm{d}$. The average nitrogen conversion to VS was about $0.769 \mathrm{mg} \mathrm{VS} / \mathrm{mg} \mathrm{NO}_{3}-\mathrm{N}$ in the $\mathrm{SSF}$.

\section{Acknowledgment}

This study was supported by the Research Fund of Cumhuriyet University (CUBAP) under Grant No. M-256, Sivas, Turkey

\section{References}

ADIN A (2003) Slow granular filtration for water reuse. Water Sci. Technol. 3 (4) 123-130.

ASLAN S AND TURKMAN A (2004) Simultaneous biological removal of endosulfan $(\alpha+\beta)$ and nitrates from drinking waters using wheat straw as substrates. Environ. Int. 30 (4) 449-455.

ASLAN S (2005) Combined removal of pesticides and nitrates in drinking waters using biodenitrification and sand filter system. Process Biochem. 40 417-424.

ASLAN S and TURKMAN A (2005) Combined biological removal of nitrate and pesticides using wheat straw as substrates. Process Biochem. 40 935-943.

ASLAN S and TURKMAN A (2006) Nitrate and pesticides removal from contaminated water using biodenitrification reactor. Process Biochem.41 882-886.

BOMO A, HUSBY A, STEVIK TK and HANSSEN JF (2003) Removal of fish pathogenic bacteria in biological sand filters. Water Res. 37 2618-2626.

BOWLES DA , DREW MW and HIRTH G (1983) The Application of Slow Sand Filtration Process to theTreatment of Small Town Water Supplies. State Rivers and Water Supply: Commission of Victoria, Australia.

CAMPOS LC, SU MFC, GRAHAM NJD and SMITH SR (2002) Biomass development in slow sand filters. Water Res. 36 4543-4551.

CHRISTOPHERSON SH, ANDERSON JL and GUSTAFSON DM (2005) Evaluation of recirculating sand filter in a cold climate. Water Sci. Technol. 51 (10) 267-272.

DAHAB MF and SIRIGINA S (1994) Nitrate removal from water supplies using biodenitrification and GAC-sand filter system. Water Sci. Technol. 30 (9) 133-139.

DELANGE B, NAKAMURA F, MYOGA H, MAGARAT Y and GUIBAL E (1994) Drinking water denitrification in a membrane bioreactor. Water Sci. Technol. 30 (6) 157-160.

ELEFSINIOTIS P and LI D (2006) The effect of temperature and carbon source on denitrification using volatile fatty acids. Biochem. Eng. J. 28 (2) 15 148-155.

ELLIS KV (1985) Slow sand filtration. CRC Crit. Rev. Environ. Control 15 (4) $315-354$. 
EU (1998) Council Directive 98/83/EC of 3 November 1998 on the quality of water intended for human consumption. Official Journal L 330, 05/12/1998 P. $0032-0054$.

MATEJU V, CIZINSKA S, KREJEI J and JANOCH T (1992) Biological water denitrification: A review. Enzyme Microb. Technol. 14 170-183.

NAKHLA G and FAROOQ S (2003) Simultaneous nitrification-denitrification in slow sand filter. J. Hazard. Mat. B96 291-303.

RICHARDY R (1989) Operating experience of full-scale biological and ion-exchange denitrification plants in France. J. Inst. Water Environ. Manage. 3 154-165.

ROCCA D R, BELGIORNO V and MERIÇ S (2005) Cotton-supported heterotrophic denitrification of nitrate-rich, drinking water with a sand filtration post-treatment. Water SA 31 229-236.
RODGERS M, HEALY MG and MULQUEEN J (2005) Organic carbon removal and nitrification of high strength wastewaters using stratified sand filters. Water Res. 39 3279-3286.

STANDARD METHODS (1995) Standard Methods for the Examination of Water and Wastewater $\left(19^{\text {th }}\right.$ edn.). American Public Health Association/American Water Works Association/Water Environment Federation (APHA, AWWA, WPCF) Washington DC, USA.

TIMMS S, SLADE JS and FRICLER CR (1995) Removal of Cryptosporidium by slow sand filtration. Water Sci. Technol. 31 (5-6) 81-84.

USEPA Consumer Factsheet on: NITRATES/NITRITES, http://www. epa.gov/ogwdw/dwh/c-ioc/nitrates.html

WHO (1984) Guidelines for Drinking Water Quality. Recommendations Vol. 1. Geneva: World Health Organization. 
Available on website http://www.wrc.org.za ISSN 0378-4738 = Water SA Vol. 34 No. 1 January 2008 ISSN 1816-7950 = Water SA (on-line) 